\title{
2 .電球形蛍光ランプのコンパクト化
}

\section{畠山篤史 等々力勝彦 小川壮一郎 \\ （株式会社日立製作所）}

1.はじめに

電球形蛍光ランプは, 電球代替の省エネルギー光源として, 需要拡大が進 んでいる。また発光管小形化技術の進歩, 電子部品の小形, 高性能化により, 電球形蛍光ランプは小形，省電力化に拍車がかかっている。今回 3 連U形発 光管をグローブで覆った電球形蛍光ランプを開発したので，その概要を報告 する。

\section{2. 開発目標}

(1) 発光管及び点灯回路の小形化を行い, ランプ形状のコンパクト化を図る。

(2) 消費電力は従来の $15 \mathrm{~W}$ 形と新規の高出力 $23 \mathrm{~W}$ 形, 形状は $\mathrm{G}$ (球) 形と $\mathrm{T}$ (円 筒) 形の合計 4 タイプを開発する。

(3) 発光管にアマルガムを用い,グローブで覆って高温となる発光管の光束低 下を防止する。

\section{3. 結果}

\section{(1) 発光管設計}

(1) $\phi 12 \mathrm{~mm}$ のガラス管をU字形に曲げ, それを 3 本接合した 3 連U形発光管 を新たに開発し，発光管高さを短縮 した。

(2)アマルガムを採用し，水銀蒸気圧 を適正に保つことにより，広い温度 範囲に渡り光束低下を防止した。

(3) 補助アマルガムの採用により, 点 灯初期の光束立ち上がりを改善した。 (2) 点灯回路設計

チップ部品の採用及びディスクリ 一ト部品の小形化, 集中配置により 点灯回路を小形化した。（基板面積： 従来比 $53 \%$ )

(3) 構造設計

プリント基板及び点灯回路を収納 するケースを共用化し，組立性の簡

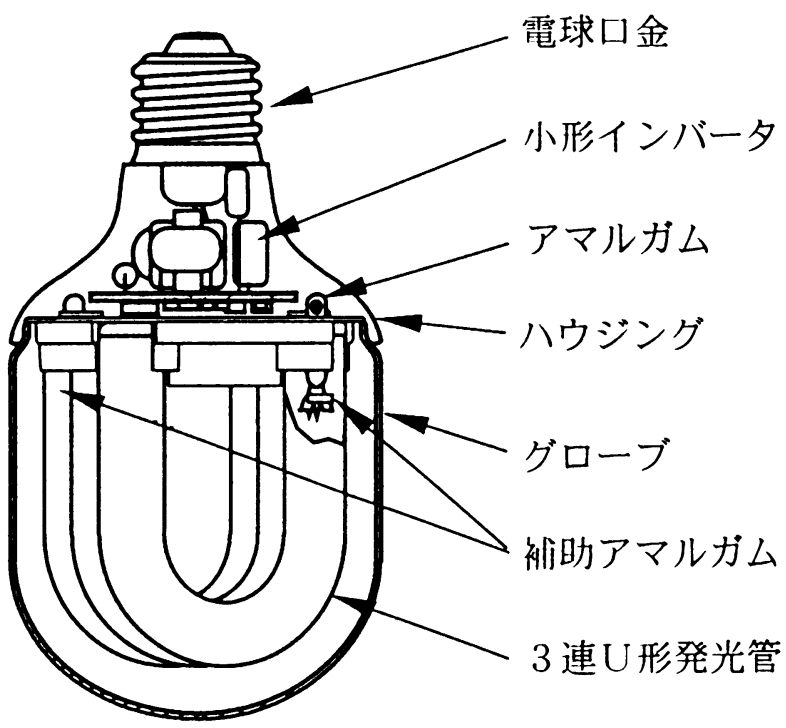

Fig.1 Outline of new lamp 易化を図った。

4.まとめ

図 1 に開発品の構造図, 表 1 に 開発品の諸特性を示す。

発光管及び点灯回路の小形化に よりランプ形状をコンパクト化し， 更に電球サイズに近似したランプ を開発したことにより，電球代替 の省エネルギー光源として, 今後 一層の普及が期待される。
Table.1 Characteristics of new lamp

\begin{tabular}{|c|c|c|c|c|}
\hline & 電球 $100 \mathrm{~W}$ 相等品 & \multicolumn{1}{c|}{ 電球 60W 相等品 } \\
\hline 型式 & EFT 23 & EFG 23 & EFT 1 & EFG 15 \\
\hline 定格電力 & $23 \mathrm{~W}$ & $23 \mathrm{~W}$ & $15 \mathrm{~W}$ & $15 \mathrm{~W}$ \\
\hline 全光束 & $14601 \mathrm{~m}$ & $13201 \mathrm{~m}$ & $7801 \mathrm{~m}$ & $7801 \mathrm{~m}$ \\
\hline 定格寿 命 & $6000 \mathrm{~h}$ & $6000 \mathrm{~h}$ & $6000 \mathrm{~h}$ & $6000 \mathrm{~h}$ \\
\hline 全長 & $149 \mathrm{~mm}$ & $135 \mathrm{~mm}$ & $130 \mathrm{~mm}$ & $130 \mathrm{~mm}$ \\
\hline 外径 & $70 \mathrm{~mm}$ & $95 \mathrm{~mm}$ & $70 \mathrm{~mm}$ & $90 \mathrm{~mm}$ \\
\hline 重量 & $170 \mathrm{~g}$ & $170 \mathrm{~g}$ & $150 \mathrm{~g}$ & $150 \mathrm{~g}$ \\
\hline
\end{tabular}

Development of smaller electronic self-ballasted fluorescent lamp. Atsushi Hatakeyama, Katsuhiko Todoroki, Soichiro Ogawa 